\title{
SCIENCE LEARNING MOTIVATION AS CORRELATE OF STUDENTS' ACADEMIC PERFORMANCES
}

\author{
Nhorvien Jay P. LIbao $\mathbb{D}$, Jessie John B. Sagun $\mathbb{D}$, Elvira A. Tamangan $\mathbb{D}$,

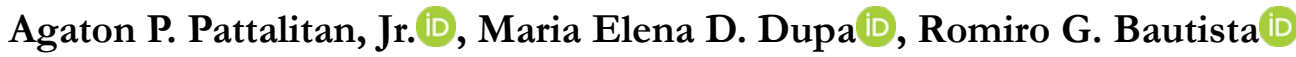 \\ College of Teacher Education, Quirino State University (Philippines) \\ nhorvienjayl@gmail.com, jessiejohnsagun@gmail.com, elviraapigotamangan@gmail.com, \\ agatonpattalitanjr@gmail.com, mariaelena.dupa@gmail.com, *corresponding author: bautista.romer@yahoo.com
}

Received June 2016

Accepted September 2016

\section{Abstract}

This study was designed to analyze the relationship of students' learning motivation and their academic performances in science. The study made use of 21 junior and senior Biological Science students to conclude on the formulated research problems. The respondents had a good to very good motivation in learning science. In general, the extent of their motivation did not vary across their sex, age, and curriculum year. Moreover, the respondents had good academic performances in science. Aptly, extrinsic motivation was found to be related with their academic performances among the indicators of motivations in learning science.

Keywords - Motivation, Science Learning, Academic Performances. 


\section{Introduction}

Science learning, at the helm of the 21 st century, is confronted with the relevance of science and technology to the societal needs and demands. In its concordance to relevance, science learning is paramount to reshape the mental cognition of students towards academic performance and the acquisition of the desired competencies, e.g., subject specific skills and general and transferable scientific skills (Lavigne, Vallerand \& Miquelon, 2007; Bautista, 2012).

Purportedly, academic performance in science is equated to students' motivation and interests in the academic pursuits that they do, e.g., scientific cognition that they are exposed with in school science (Osborne \& Collins, 2001; Jegede, 2007; Barmby, Kind \& Jones, 2008). Aptly, science learning is to engage and expose students in a meaningful learning condition that constantly make them wander in a sustained culture of practice (Reis, 2000; Osborne \& Collins, 2001). Science education, in this sense, impinges relevance in the following states:

- the societal impact of science;

- students' motivation and interests towards science learning; and

- the importance of science in the course that they are taking (Holbrook, Rannikmae, Yager \& DeVreese, 2003).

This means that the content learnt in school science is imperatively meaningful and of great use to student-learners as they establish a framework of self-perceived competence, security in supportive relationships (relatedness), and self-driven purpose (autonomy)-three basic needs required for people to experience social and emotional growth (Ryan \& Deci, 2000). This affordance leads student-learners to develop better motivation and interests that leads them to become academically and technically enabled learners and lovers of science.

Concomitantly, science learning is encapsulated in the following tenets:

- learning science is an active process of constructing personal knowledge;

- learners come to science learning with existing ideas about many natural phenomenon attributed to their mental readiness and cognition;

- learner's existing ideas have consequences for the learning of science;

- it is possible to teach science more effectively if account is taken of the learner's existing ideas; and 
- knowledge is represented in the brain as a conceptual structure (Taber, 2008; Bautista, 2012).

The crux is: motivation and interests of students in science learning are underscored as supporting conditions to the central dogma of academic performance and critical thinking in school science. Moreover, motivation refers to reasons that underlie behavior that is characterized by the students' interests, willingness, and volition (Beal \& Stevens, 2011). Apropos of, the impact of motivation in science learning is construed to be the pole-vaulting factor that hones their performances in school science. Motivation in science learning, in this sense, includes extrinsic and intrinsic motivation, task value, control of learning beliefs, self-efficacy, and test anxiety (Tuana, Chin \& Shieh, 2005; Bautista, 2012). Hence, this study was conducted.

\subsection{Objectives of the Study}

This study was designed to establish evidences on science learning motivation as correlate of students' academic performances in the major content courses in the Biological Science program. Specifically, this study aimed to provide explanations on the:

- extent of the respondents' motivation in learning science in terms of:

- intrinsic motivation;

- extrinsic motivation;

- task value;

- control of learning beliefs;

$\circ \quad$ self-efficacy; and

- test anxiety;

- $\quad$ students' academic performances in the science courses;

- significant differences on the students' motivation in learning science when grouped according to profile; and

- significant relationship between students' motivation and academic performance in science. 


\section{Design/methodology/approach}

The Descriptive Research design was used in this study as it tried to gather data on the prevalence of students' motivation in science learning as correlated with their academic performances. Motivation in science learning includes intrinsic motivation, extrinsic motivation, task value or relevance, control of learning beliefs and determination, self-efficacy, and test anxiety. This research design fits best in studies which aim is to describe the nature of situations as it exists at the time of the study and to explore the cause of a particular phenomenon. Among the various types of descriptive research design, four were rightly applied: survey, in-depth study, correlation, and comparison.

This research was conducted at the College of Teacher Education of Quirino State University, Diffun Campus, School Year 2015-2016. A total of 21 respondents were determined using the Lynch Formula. As to sex, four were males and 17 were females; age, nine belong to 17 - 19, nine from 20 - 22, and three from 23 and above; and curriculum year, 11 were third year and 10 were fourth year. The respondents were the Bachelor of Secondary Education (BSE) students majoring in Biological Science. They were selected based on the assumption of the researchers that they were already at the peak of their studies which enabled them to have employed various motivational techniques and strategies in their courses of studies.

The research instrument is adopted from the study of Tuana, Chin and Shieh (2005) on the measurement of students' motivation towards science learning. The gathered data were treated with mean, t-test, Pearson-r, and ANOVA: all were employed in SPSS.

\section{Results and Discussion}

\begin{tabular}{|l|l|c|c|c|c|}
\hline \multicolumn{2}{|c|}{ Types of Motivation } & \multicolumn{2}{c|}{ Male } & \multicolumn{2}{c|}{ Female } \\
\hline $\mathbf{1}$ & Intrinsic Motivation & $3.500^{\mathrm{A}}$ & VTM & $3.544^{\mathrm{A}}$ & VTM \\
\hline $\mathbf{2}$ & Extrinsic Motivation & $2.750^{\mathrm{A}}$ & TM & $3.515^{\mathrm{B}}$ & VTM \\
\hline $\mathbf{3}$ & Task Value & $3.833^{\mathrm{A}}$ & VTM & $3.755^{\mathrm{A}}$ & VTM \\
\hline $\mathbf{4}$ & Control of Learning Beliefs & $3.375^{\mathrm{A}}$ & $\mathrm{TM}$ & $3.294^{\mathrm{A}}$ & TM \\
\hline $\mathbf{5}$ & Self-efficacy & $3.156^{\mathrm{A}}$ & $\mathrm{TM}$ & $3.412^{\mathrm{A}}$ & TM \\
\hline $\mathbf{6}$ & Test Anxiety & $2.100^{\mathrm{A}}$ & NTM & $2.494^{\mathrm{A}}$ & NTM \\
\hline
\end{tabular}

Legend: NTM - Not True of Me; TM - True of Me; VTM - Very True of Me

Table 1. The Respondents' Motivation in Science Learning when Grouped by Sex ${ }^{1}$

( ${ }^{1}$ Means of the same letter within rows are comparable at .05 level of significance (t-test)) 
Based on the foregoing results, it can be said that there is a good to very good state of motivation among the respondents. However, a disparity exists between the respondents' affordance of extrinsic motivation. This implies that females are more extrinsically motivated than their male counterparts. Concomitant to this affordance is a potential threat of distraction among the respondents from true independent learning (Ryan \& Deci, 2000) as this type of motivation produces immediate results and requires less effort in comparison with intrinsic motivation. Aptly, when rewards are removed, students lose their motivation (DeLong \& Winter, 2002).

Alarmingly, this concordance has become an international phenomenon as claimed in the Relevance of Science Education (ROSE) project conducted in over 20 countries (Schreiner \& Sjøberg, 2004). It is zeroed in that girls are liking school science education significantly less than their male counterparts.

\begin{tabular}{|l|l|c|c|c|c|c|c|}
\hline \multicolumn{2}{|c|}{ Types of Motivation } & \multicolumn{2}{c|}{$\mathbf{1 7 - 1 9}$} & \multicolumn{2}{c|}{$\mathbf{2 0 - 2 2}$} & \multicolumn{2}{c|}{$\mathbf{2 3}$ and above } \\
\hline $\mathbf{1}$ & Intrinsic Motivation & $3.525^{\mathrm{A}}$ & VTM & $3.556^{\mathrm{A}}$ & VTM & $3.500^{\mathrm{A}}$ & VTM \\
\hline $\mathbf{2}$ & Extrinsic Motivation & $3.375^{\mathrm{A}}$ & TM & $3.444^{\mathrm{A}}$ & TM & $3.000^{\mathrm{A}}$ & TM \\
\hline $\mathbf{3}$ & Task Value & $3.617^{\mathrm{A}}$ & VTM & $3.889^{\mathrm{A}}$ & VTM & $4.000^{\mathrm{A}}$ & VTM \\
\hline $\mathbf{4}$ & Control of Learning Beliefs & $3.300^{\mathrm{A}}$ & TM & $3.222^{\mathrm{A}}$ & TM & $3.750^{\mathrm{A}}$ & VTM \\
\hline $\mathbf{5}$ & Self-efficacy & $3.275^{\mathrm{A}}$ & TM & $3.403^{\mathrm{A}}$ & TM & $3.625^{\mathrm{A}}$ & VTM \\
\hline $\mathbf{6}$ & Test Anxiety & $2.580^{\mathrm{A}}$ & TM & $2.400^{\mathrm{A}}$ & NTM & $2.100^{\mathrm{A}}$ & NTM \\
\hline
\end{tabular}

Table 2. The Respondents' Motivation in Science Learning when Grouped by Age

('Means of the same letter within rows are comparable at .05 level of significance (ANOVA))

Presented in the foregoing table are the respondents' motivation in science learning when grouped by age. It can be said that there are comparable affordances of the respondents on their motivation in science learning. Furthermore, it can be said that the respondents' motivation increases qualitatively as they progress with their age. It is claimed that motivation, corollary to the respondents' current experiences, mental readiness, and academic acumen, is inconclusive as individuals are susceptible with their age inequities (Greene \& DeBacker, 2004; Jegede, 2007). This implies that motivation changes as people get older and fortified with their academic and cultural endowment, hence academic mentors must provide an enriching leap to develop further their motivation in science learning (Chow \& Yong, 2013). 


\begin{tabular}{|l|l|c|c|c|c|}
\hline \multicolumn{2}{|c|}{ Types of Motivation } & \multicolumn{2}{c|}{ Third Year } & \multicolumn{2}{c|}{ Fourth Year } \\
\hline $\mathbf{1}$ & Intrinsic Motivation & $3.500^{\mathrm{A}}$ & VTM & $3.575^{\mathrm{A}}$ & VTM \\
\hline $\mathbf{2}$ & Extrinsic Motivation & $3.341^{\mathrm{A}}$ & TM & $3.400^{\mathrm{A}}$ & TM \\
\hline $\mathbf{3}$ & Task Value & $3.636^{\mathrm{A}}$ & VTM & $3.917^{\mathrm{B}}$ & VTM \\
\hline $\mathbf{4}$ & Control of Learning Beliefs & $3.318^{\mathrm{A}}$ & $\mathrm{TM}$ & $3.300^{\mathrm{A}}$ & TM \\
\hline $\mathbf{5}$ & Self-efficacy & $3.284^{\mathrm{A}}$ & $\mathrm{TM}$ & $3.450^{\mathrm{A}}$ & TM \\
\hline $\mathbf{6}$ & Test Anxiety & $2.545^{\mathrm{A}}$ & TM & $2.280^{\mathrm{A}}$ & NTM \\
\hline
\end{tabular}

Table 3. The Respondents' Motivation in Science Learning when Grouped by Curriculum Year ${ }^{1}$

( ${ }^{1}$ Means of the same letter within rows are comparable at .05 level of significance (t-test))

Presented in the foregoing table are the respondents' motivation in learning science when grouped by curriculum year. It presents that there are comparable affordances of the respondents on the various types of motivation except for task values. Results reveal that fourth year respondents have better affordance of task value than their third year counterparts. This concordance could be attributed to the varying internal level of the respondents' attitude that drives their motivation into its optimum level as theorized by Ryan and Deci in their Cognitive Evaluation Theory, hence motivation given to a student-learner must fall within his current level of competency (Ryan \& Deci, 2000).

However, there has been a decline in the interests of students in school science education (Chow \& Yong, 2013; Margolis \& McCabe, 2006; Jegede, 2007). This scientific-educational alienation threatens the notion of scientific identity which could only be recuperated through classroom pedagogical interventions, i.e. demonstrating motivational scientific attitude and acumen and the empirical impact of science to technology and society.

\begin{tabular}{|c|c|c|c|c|c|c|c|c|c|c|c|c|}
\hline \multirow{2}{*}{$\begin{array}{l}\text { Science } \\
\text { Courses }\end{array}$} & \multicolumn{2}{|c|}{ Excellent } & \multicolumn{2}{|c|}{ Superior } & \multicolumn{2}{|c|}{ Very Good } & \multicolumn{2}{|c|}{ Good } & \multicolumn{2}{|c|}{ Average } & \multicolumn{2}{|c|}{ Below average } \\
\hline & Freq & $\%$ & Freq & $\%$ & Freq & $\%$ & Freq & $\%$ & Freq & $\%$ & Freq. & $\%$ \\
\hline $\begin{array}{l}\text { General } \\
\text { Biology }\end{array}$ & 1 & 4.8 & 4 & 19 & 2 & 9.5 & 11 & 52.4 & 3 & 14.3 & - & - \\
\hline Botany & 2 & 9.5 & 1 & 4.8 & 8 & 38.1 & 9 & 42.9 & 1 & 4.8 & - & - \\
\hline $\begin{array}{l}\text { General } \\
\text { Zoology }\end{array}$ & 2 & 9.5 & 1 & 4.8 & 6 & 28.6 & 7 & 33.3 & 4 & 19 & 1 & 4.8 \\
\hline $\begin{array}{l}\text { Human } \\
\text { Anatomy }\end{array}$ & - & - & - & - & 5 & 23.8 & 9 & 42.9 & 6 & 28.6 & 1 & 4.8 \\
\hline Cell Biology & - & - & 6 & 28.6 & 5 & 23.8 & 5 & 23.8 & 5 & 23.8 & - & - \\
\hline $\begin{array}{l}\text { Organic } \\
\text { Chemistry }\end{array}$ & 2 & 9.5 & 6 & 28.6 & 6 & 28.6 & 6 & 28.6 & 1 & 4.8 & - & - \\
\hline $\begin{array}{l}\text { Inorganic } \\
\text { Chemistry }\end{array}$ & - & - & 5 & 23.8 & 6 & 28.6 & 9 & 42.9 & 1 & 4.8 & - & - \\
\hline
\end{tabular}

Table 4. The Respondents' Academic Performances in Science 
Respondents are mostly good in General Biology, Botany, General Zoology, Cell Biology, Organic Chemistry, and Inorganic Chemistry. It can be noted that the scores are skewed to the right where some of the respondents are excellent performers. Rare cases are seen in General Zoology and Human Anatomy with one respondent who is seen to be a deviant among his counterparts in the group. This poses careful attention among the teachers in the department as this state could threaten his future career. Research evidence shows that it is indeed the quality of the educational experiences provided by teachers - the learning and teaching methods used which play a potential role in students' success in taking up science, technology, engineering, and mathematics (STEM). Furthermore, it is underscored that good quality teachers are more important than any other factor (Osborne \& Collins, 2001; Schreiner \& Sjøberg, 2004).

\begin{tabular}{|c|c|c|c|c|c|c|c|c|}
\hline & & $\begin{array}{c}\text { Gen. } \\
\text { Biology }\end{array}$ & Botany & $\begin{array}{c}\text { Gen. } \\
\text { Zoology }\end{array}$ & $\begin{array}{l}\text { Human } \\
\text { Anatomy }\end{array}$ & $\begin{array}{c}\text { Cell } \\
\text { Biology }\end{array}$ & $\begin{array}{c}\text { Organic } \\
\text { Chem }\end{array}$ & $\begin{array}{l}\text { Inorg. } \\
\text { Chem }\end{array}$ \\
\hline \multirow{3}{*}{ Intrinsic } & $\begin{array}{c}\text { Pearson } \\
\text { Correlation }\end{array}$ & -.005 & .198 & .099 & .077 & .228 & .123 & .162 \\
\hline & Sig. (2-tailed) & .983 & .389 & .671 & .741 & .320 & .595 & .484 \\
\hline & $\mathbf{N}$ & 21 & 21 & 21 & 21 & 21 & 21 & 21 \\
\hline \multirow{3}{*}{ Extrinsic } & $\begin{array}{c}\text { Pearson } \\
\text { Correlation }\end{array}$ & .349 & .319 & $.587^{* *}$ & $.534^{*}$ & .432 & .240 & $.469^{*}$ \\
\hline & Sig. (2-tailed) & .121 & .159 & .005 & .013 & .051 & .294 & .032 \\
\hline & $\mathbf{N}$ & 21 & 21 & 21 & 21 & 21 & 21 & 21 \\
\hline \multirow{3}{*}{ Task Value } & $\begin{array}{c}\text { Pearson } \\
\text { Correlation }\end{array}$ & .135 & .112 & .060 & -.244 & .014 & -.032 & -.210 \\
\hline & Sig. (2-tailed) & .561 & .630 & .796 & .286 & .953 & .891 & .362 \\
\hline & $\mathbf{N}$ & 21 & 21 & 21 & 21 & 21 & 21 & 21 \\
\hline \multirow{3}{*}{$\begin{array}{c}\text { Control of } \\
\text { Learning } \\
\text { Beliefs }\end{array}$} & $\begin{array}{c}\text { Pearson } \\
\text { Correlation }\end{array}$ & -.066 & .326 & .202 & .219 & .114 & .240 & .312 \\
\hline & Sig. (2-tailed) & .775 & .149 & .380 & .341 & .623 & .295 & .169 \\
\hline & $\mathbf{N}$ & 21 & 21 & 21 & 21 & 21 & 21 & 21 \\
\hline \multirow{3}{*}{ Self-Efficacy } & $\begin{array}{c}\text { Pearson } \\
\text { Correlation }\end{array}$ & -.255 & -.023 & -.041 & .097 & -.106 & -.038 & .026 \\
\hline & Sig. (2-tailed) & .265 & .922 & .860 & .675 & .649 & .869 & .912 \\
\hline & $\mathbf{N}$ & 21 & 21 & 21 & 21 & 21 & 21 & 21 \\
\hline \multirow{3}{*}{ Test Anxiety } & $\begin{array}{c}\text { Pearson } \\
\text { Correlation }\end{array}$ & .188 & .244 & .322 & .222 & .314 & .221 & .221 \\
\hline & Sig. (2-tailed) & .415 & .286 & .155 & .333 & .166 & .335 & .335 \\
\hline & $\mathbf{N}$ & 21 & 21 & 21 & 21 & 21 & 21 & 21 \\
\hline
\end{tabular}

**. Correlation is significant at the 0.01 level (2-tailed).

*. Correlation is significant at the 0.05 level (2-tailed).

Table 5. Respondents' Motivation in Learning and their Academic Performances in Science 
Presented in the foregoing table are the associations of motivations in learning science and the academic performances of the respondents in their science courses. It can be noted that extrinsic motivations posted significant results along with their performances in General Zoology, Human Anatomy, and Inorganic Chemistry. On the other hand, no significant results were posted with the rest of the motivation types with the academic performances of the respondents.

The determinants of the following concordances post a notable feature of the contemporary scientific society as there is an emerging growing range of competencies relative to the interaction of technologies and media. It can be noted further that scientific cognition and exposures where students engaged in is the construction of a universal scientific identity in a barnone curriculum. Corollary with these factors is the engagement of the facilitators of learning towards creativity and autonomy of the learners in self-expression (Sefton-Green, 2007; Osborne \& Collins, 2001). Apparently, this post-structuralist perspectives of school science education ensure a joie de vivre state in its academic acumen contributory to curricular currency and relevancy.

\section{Conclusions}

Based on the foregoing results, the following are concluded:

- there is a good to very good state of motivation among the respondents;

- there are no significant differences on the motivations of the respondents in learning science except for extrinsic motivation when grouped by sex and task value when grouped by curriculum year;

- there is a good to excellent performances of the respondents in the different courses in science; however, a potential deviant learner was identified; and

- except for extrinsic motivation, the types of motivation in science learning are not related to the academic performances of the respondents. 


\section{References}

Bautista, R.G. (2012). The convergence of mastery learning approach and self-regulated learning learning strategy in teaching biology. Journal of Education and Practice, 3(10), 25-32.

Barmby, P., Kind, P.M., \& Jones, K. (2008). Examining changing attitudes in secondary school science. International Journal of Science Education, 30(8), 1075-1093.

http://dx.doi.org/10.1080/09500690701344966

Beal, C.R., \& Stevens, R.H. (2011). Improving students' problem solving in a web-based chemistry simulation through embedded metacognitive messages. Technology, Instrumentation, Cognition and Learning, 8(3), 255-271.

Chow, S.J., \& Yong, B.C.S. (2013). Secondary school students' motivation and achievement in combined science. US-China Education Review, 3(4), 213-228.

DeLong, M., \& Winter, D. (2002). Learning to Teaching and Teaching to Learn Mathematics: Resources for Professional Development. USA: Mathematical Association of America, 168.

Greene, B.A., \& DeBacker, T.K. (2004). Gender and orientations toward the future: Links to motivation. Educational Psychology Review, 16(2), 91-120.

http://dx.doi.org/10.1023/B:EDPR.0000026608.50611.b4

Holbrook, J., Rannikmae, M., Yager, R., \& DeVreese, P. (2003). Increasing the relevance of science education. Paper presented at The NARST 2003 Annual International Conference, March 23-26, 2003, Philadelphia, USA.

Jegede, S.A. (2007). Students' anxiety towards the learning of chemistry in some Nigerian secondary schools. Educational Research and Review, 2(7), 193-197.

Lavigne, G.L., Vallerand, R.J., \& Miquelon, P. (2007). A motivational model of persistence in science education: A self-determubation theory approach. European Journal of Psychology of Education, 22(3), 351-396. http://dx.doi.org/10.1007/BF03173432

Margolis, H., \& McCabe, P.P. (2006). Improving self-efficacy and motivation: What to do, what to say. Intervention in School Clinic, 41(4), 218-227. http://dx.doi.org/10.1177/10534512060410040401

Osborne, J.F., \& Collins, S. (2001). Pupils' views of the role and value of the science curriculum: A focus-group study. International Journal of Science Education, 23(5), 441-468. http://dx.doi.org/10.1080/09500690010006518 
Reis, H.T. (2000). The relationship context of human behavior and development. Psychological Bulletin, 126(6), 844-872. http://dx.doi.org/10.1037/0033-2909.126.6.844

Ryan, R.M., \& Deci, E.L. (2000). Intrinsic and extrinsic motivations: Classic definitions and new directions. Contemporary Educational Psychology, 25, 54-67. http://dx.doi.org/10.1006/ceps.1999.1020

Schreiner, C., \& Sjøberg, S. (2004). Sowing the seeds of ROSE. Background, Rationale, Questionnaire Development and Data Collection for ROSE (The Relevance of Science Education) - a comparative study of students' viens of science and science education (pdf) (Acta Didactica 4/2004). Oslo: Dept. of Teacher Education and School Development, University of Oslo.

Sefton-Green, J. (2007). Youth, Technology, and Media Culture. Review of Research in Education, 30, 279-306. http://dx.doi.org/10.3102/0091732X030001279

Taber, K.S. (2008). Exploring student learning from a constructivist perspective in diverse educational contexts. Journal of Turkish Science Education, 5(1), 2-21.

Tuana, H.L., Chin, C.C., \& Shieh, S.H. (2005). The development of a questionnaire to measure students' motivation towards science learning. International Journal of Science Education, 27(6), 639654. http://dx.doi.org/10.1080/0950069042000323737

\section{Published by OmniaScience (www.omniascience.com) \\ Journal of Technology and Science Education, 2016 (www.jotse.org)}

\section{(a)}

Article's contents are provided on an Attribution-Non Commercial 3.0 Creative commons license. Readers are allowed to copy, distribute and communicate article's contents, provided the author's and JOTSE journal's names are included. It must not be used for commercial purposes. To see the complete licence contents, please visit http://creativecommons.org/licenses/by-nc/3.0/es/ 